\title{
42 ネオンランプの放電開始遅れ
}

\author{
奥田 祥之典 村上 哲宣 酒井 正道 関根 勝吾 \\ （ハリソン電譏株式会社）
}

1.はじめに

従来より、ネオンランブは、家审製品等のインジケーター、 襩写機のイレーサー用光源、カメラ用人トロボフラッシュの充 電電圧表示、電子機器のサージアプソーバーなどに使用されて いる。ここでは主にサージアプーバー用ネオンランプの諸特 性に対する特性因子について実騒した結果を報告する。

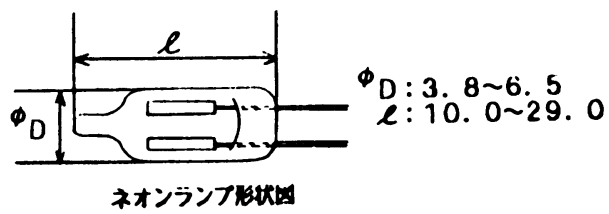

⿶1

2. 用途別要求特吽

用途に忍じた諸特性は、困2，3の通りである。

3.サージアアノーバー用ネオンシンプの必要特性と設計要素

サージアフソーバー用に要求される諸特性項目

とそれに関連する必要特性及び設計要素との関係

は表フのように考えられる。

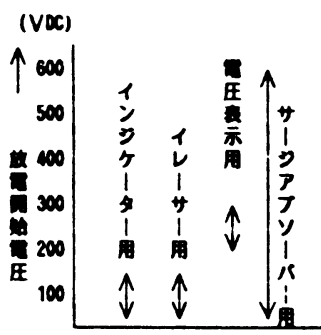

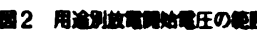

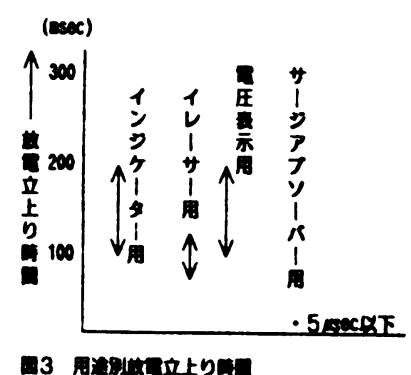

表1 サージアプソーバー用ネオンランプの必要特性と設計要素

\begin{tabular}{|c|c|c|}
\hline 特性項目 & 必要特性 & 設 計 要 \\
\hline 放电開始阵压 & $70 \sim 600$ VDC & 宣栓間隔，封入ガス組成，封入压，電子放射性物質組成 \\
\hline 放馣立上り時間 & $5 \mu$ sec以下 & 封入ガスの種類，補情効果，ラジオアイソトープ塗布量 \\
\hline 紿緣抵抗 & $10^{9}$ 几以上 & 補極材質及び塗布冝 \\
\hline
\end{tabular}

\section{4. 奏涘及び結果}

サージアフソーバー用として、特に要求される特性のひとつ

として、暗黙中でのサージに対する放電这上り時間がある。

暗黑放電改善のため迪常、微量のラジオアイソトーフを電植に メッキするが、これだけでは苃求される放龟立上り時間が得ら れない。そこで、封入ガス組成及び補树勃果について実涘を行 つた。汹4にアルゴン,ネオン混合ガスでの実験結果を示す。 放電可上り时間は、アルゴン $75 \%$ ，ネオン $25 \%$ の混合ガス

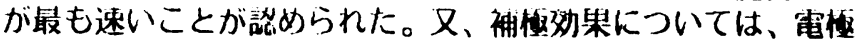
間のバルブ内表面にアルミニウム粉末を塗布したが、アルミニ

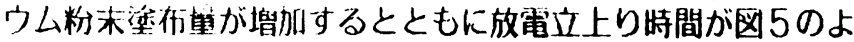
うに頙著に速くなることが誌められた。

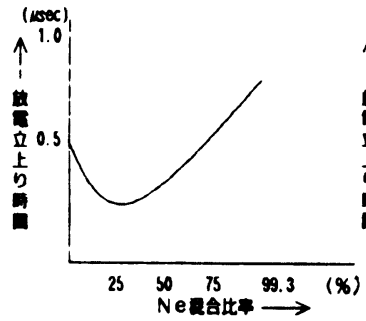

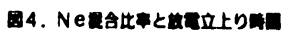

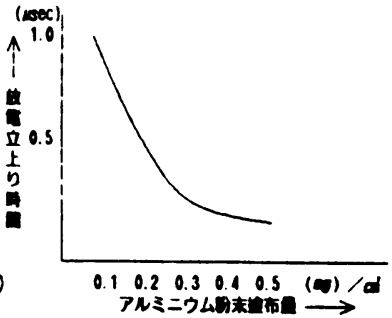

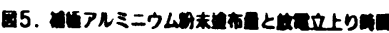

5.あとがき

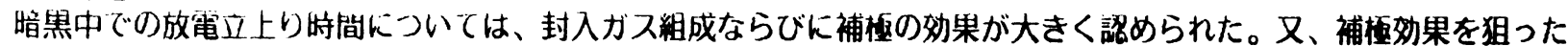
アルミニウム粉末塗布搵を増重すると、絈䋑抵抗が下がる傾向が認められるため、アルミニウム塗布重は、絶縁抵抗の要 請により一定蜕井に押さえる必要がある。

Starting time lag of neon lamp discharging

Shounosuke Okuda letsunobu Murakami Masamichi Sakai Shougo Sekine 